\title{
Anti-Tumour Necrosis Factor Therapy for Paediatric Crohn's Disease: Improved Benefits Through Treatment Optimisation, Deeper Understanding of Its Risks, and Reduced Costs due to Biosimilar Availability
}

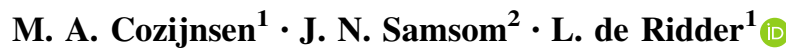

Published online: 27 October 2017

(C) The Author(s) 2017. This article is an open access publication

\begin{abstract}
Antibodies directed to tumour necrosis factor- $\alpha$ (TNF- $\alpha$ ) are very effective in treating paediatric Crohn's disease (CD). Over the last few years, research has provided important new insights into how to optimise this treatment's effectiveness. Research on predictors for anti-TNF treatment responsiveness has revealed potential markers, but data on their accuracy in paediatric CD patients are lagging behind. Also, new evidence has become available on the safety profile of anti-TNF antibodies that suggests the assumed increased malignancy risk seen in patients on antiTNF and thiopurine combination treatment may be linked more to thiopurine use and not to anti-TNF treatment. In addition, the early results of CT-P13, an infliximab biosimilar, in $\mathrm{CD}$ patients confirm the expected similarity with its originator. Thus, the effectiveness of antiTNF antibody treatment is slowly improving, its malignancy risk is lower than assumed, and its costs are reduced by the introduction of equally effective biosimilars. Together, these trends allow for a more prominent role for anti$\mathrm{TNF}$ antibodies in future treatment of paediatric $\mathrm{CD}$.
\end{abstract}

L. de Ridder

1.deridder@erasmusmc.nl

1 Department of Paediatric Gastroenterology, Erasmus University Medical Centre-Sophia Children's Hospital, P.O. Box 2060, 3000 CB Rotterdam, The Netherlands

2 Laboratory of Paediatrics, Erasmus University Medical Centre-Sophia Children's Hospital, Rotterdam, The Netherlands

\section{Key Points}

The number of predictive markers of anti-tumour necrosis factor (TNF) treatment responsiveness in Crohn's disease (CD) is growing, but their implementation into clinical care for paediatric CD patients is hampered by a lack of evidence for their applicability in the paediatric population.

New evidence suggests that the increased risk of malignancies seen in patients treated with anti-TNF thiopurine combination therapy is not linked to antiTNF treatment in itself, implying a slightly more favourable benefit-risk ratio for anti-TNF treatment than previously assumed.

Early results confirm the expected efficacy and safety similarity between the infliximab biosimilar CT-P13 and its originator in paediatric CD.

\section{Introduction}

Crohn's disease (CD) is an inflammatory bowel disease (IBD) of unknown origin. It is a chronic, relapsing-remitting disease characterised by gastrointestinal symptoms, weight loss and fatigue, co-existing with increased concentrations of inflammatory proteins in blood and stool, and an inflamed intestine. CD may have a complicated disease course with the formation of fistulas or intestinal strictures. Immunosuppressive treatment is required for inducing and maintaining disease remission and preventing development of these complications. Childhood onset CD develops in approximately four per 100,000 children [1]. 
The paediatric disease course usually is more extensive and progressive than adult-onset $\mathrm{CD}$, and as a result, more intense treatment is required [2,3]. After diagnosis, steroids and exclusive enteral nutrition (EEN) are regularly started first, to induce remission, together with thiopurines or methotrexate (MTX) to maintain remission.

Anti-tumour necrosis factor- $\alpha$ (anti-TNF- $\alpha$ ) antibodies have been shown to be very effective in inducing and maintaining remission in therapy refractory paediatric $\mathrm{CD}$ patients [4, 5]. Anti-TNF treatment not only induces remission of clinical symptoms, it also restores mucosal tissue integrity, denoted as endoscopic remission [6]. Since its approval, researchers have searched for ways to optimise anti-TNF antibody usage to increase response rates and to prolong the duration of disease remission. Based on their findings, the use of anti-TNF antibodies in managing paediatric CD has significantly evolved over time. This article highlights new insights in the treatment's mechanisms of action, discusses optimisation methods for antiTNF therapy, new data on malignancy risk, and efficacy and safety data on anti-TNF biosimilars in paediatric CD.

\section{Pathogenesis of Crohn's Disease (CD) and Tumour Necrosis Factor (TNF)}

The pathogenesis of CD is highly complex and still not fully understood. CD is a multifactorial disease in which genetic predisposition, microbial and dietary environmental pressure, and susceptibilities of the immune system lead to aberrant inflammatory responses to luminal microbiota and concomitant autoimmune responses. Although a cure has not yet been found, manipulating one of these factors does alleviate disease. For example, diversion of luminal content with a stoma, which drastically alters environmental pressure, reduces mucosal inflammation in the bowel distal to the stoma. In addition, dietary intervention with EEN, which affects luminal microbial composition, also inhibits inflammation and can restore the integrity of the mucosal layer. Lastly, inhibiting the immune response also has strong beneficial effects, as most clearly evidenced by the effect of immune-suppressive and immune-modulating interventions on $\mathrm{CD}$. A key problem in the chronicity of $\mathrm{CD}$ is the development of immune memory driven by $\mathrm{T}$ lymphocytes ( $\mathrm{T}$ cells) that reside in the intestinal lamina propria, secrete interferon- $\gamma$ and cause reactivation of the disease upon recognition of their environmental activating trigger [7]. Effective elimination or inhibition of this cell population may reduce the chance of disease re-activation and explains why $\mathrm{T}$ cells are an important target in CD treatment strategies.

TNF is an inflammatory cytokine mainly produced by macrophages, although it can also be produced by many other leukocytes, for example $\mathrm{T}$ cells. It is produced as a transmembrane protein (tmTNF) and a soluble form (sTNF). TNF- $\alpha$ is an important factor for orchestrating cellular immune responses and plays a crucial role in host defence to pathogens and killing of malignant cells. TNF signals via two receptors: TNF receptor type 1 (TNFR1), expressed in almost all cell types, and TNFR2, expressed on leukocytes only. Ligation of the receptor results in a complex signalling cascade leading to the production of a wide variety of proteins involved in cell survival, proliferation, differentiation, migration, and apoptosis. When TNF concentrations in blood become very high, an acute phase reaction in the liver ensues, causing fever and cachexia.

\section{Mechanism of Action of Anti-TNF Antibodies in $\mathrm{CD}$}

Multiple mechanisms of action may contribute to the beneficial effect of anti-TNF antibody therapy in CD (Fig. 1). Both the antibody's binding fragment (FAB) region and the fragment crystallisable (FC) region exert immunomodulatory properties. The FAB regions of infliximab (IFX) and adalimumab (ADA) specifically bind to TNF- $\alpha$ molecules. Upon binding with its FAB region, anti-TNF antibodies block and neutralise the signalling potential of TNF. Additionally, anti-TNF antibodies bound to a tmTNF-expressing target cell suppress pro-inflammatory cytokine production or induce apoptosis in the target cell, a process denoted as reverse signalling [8-10].

Although it was anticipated that anti-TNF antibodies would primarily exert their beneficial function in $\mathrm{CD}$ by neutralising TNF function through its FAB regions, it is now recognised that the FC tail of the antibody is important for effectiveness. Etanercept-a TNF receptor/immunoglobulin $\mathrm{G}$ fusion protein, capable of neutralising sTNF-has been shown to be ineffective in CD [11]. Secondly, certolizumab pegol-a PEGylated FAB fragment of an anti-TNF antibody that lacks an FC regionhad only low efficacy in CD [12]. The poor efficacy of these biologicals that are effective for the treatment of other chronic inflammatory diseases (rheumatoid arthritis, psoriatic arthritis and ankylosing spondylitis among others) may suggest that the FC region has a crucial role in inducing immunomodulation in $\mathrm{CD}$. The $\mathrm{FC}$ region enables bound antibodies to elicit complement-dependent cytotoxicity (CDC) and antibody-dependent cell-mediated cytotoxicity (ADCC) [13]. Secondly, it enables an antibody-antigen complex to bind with cells presenting an FC receptor, such as macrophages. Based on in vitro experiments, it is suggested that TNF-anti-TNF immune complexes may lead to the induction of immunosuppressive 


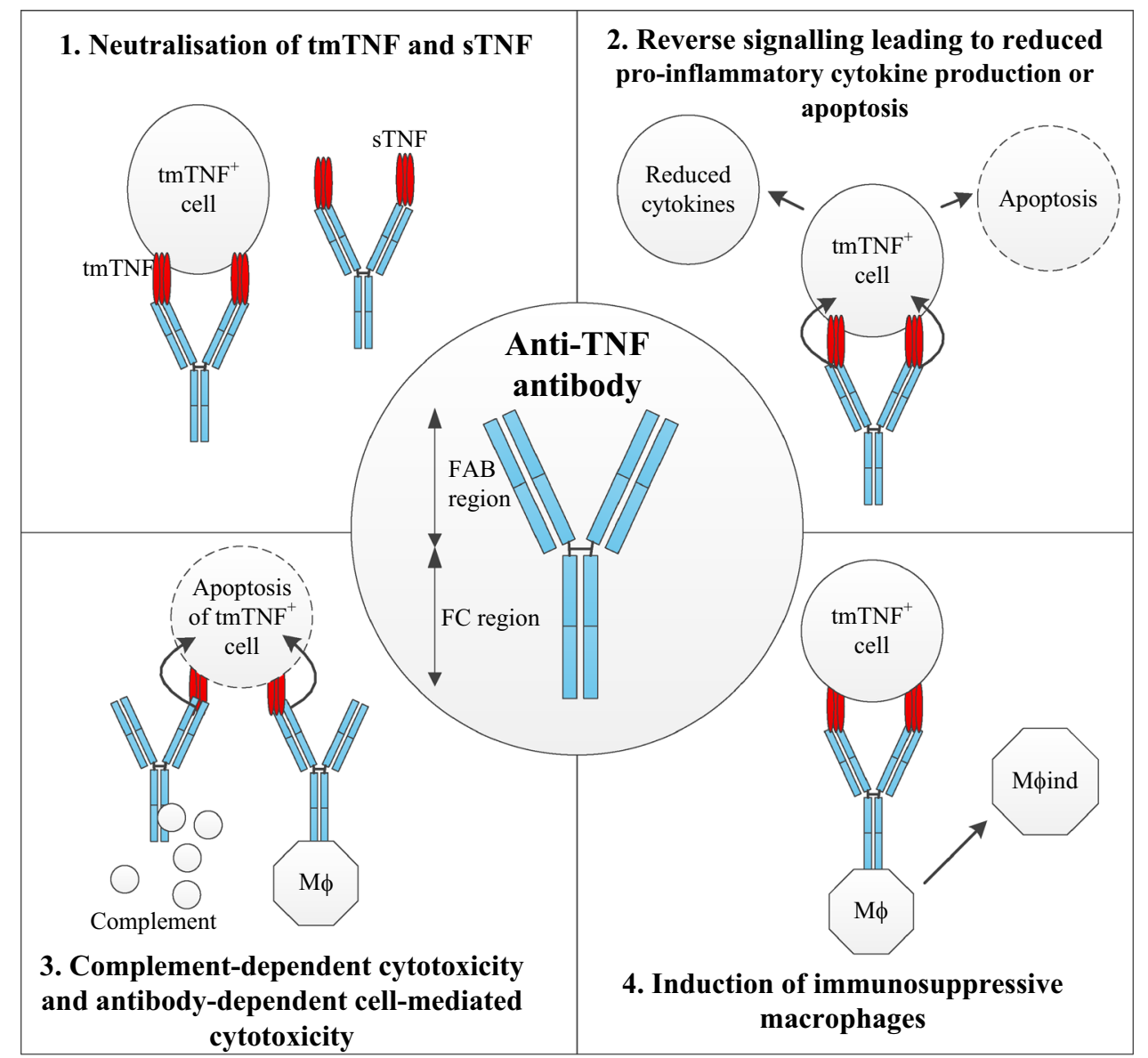

Fig. 1 Overview of the mechanisms of action of anti-tumour necrosis factor (TNF) antibodies. Displayed are four mechanisms of action of anti-TNF antibodies in treating Crohn's disease (CD). Via its binding fragment $(\mathrm{FAB})$ region, anti-TNF antibodies can (1) neutralise both soluble (s) TNF and transmembrane (tm) TNF and (2) elicit reverse signalling that can reduce pro-inflammatory cytokine production of the $\operatorname{tmTNF}^{+}$cell or induce apoptosis. Through its fragment crystallisable (FC) region, (3) complement and natural killer (NK)

macrophages, able to produce anti-inflammatory proteins, inhibit T-cell proliferation and promote wound healing $[14,15]$. The induction of these immunosuppressive macrophages may partly explain the higher effectiveness of anti-TNF antibodies that possess an FC region, but this hypothesis still needs to be proven.

\section{Efficacy of Anti-TNF Antibodies}

Both IFX and ADA are efficacious in the treatment of paediatric $\mathrm{CD}$ and are considered equally effectivealthough a head-to-head comparison is lacking [16]. They can both be used to induce and maintain remission in paediatric $\mathrm{CD}$ patients. The available prospective trials demonstrate that more than $80 \%$ of therapy refractory patients respond to induction treatment with anti-TNF cells-among others-can bind to the antibodies and can elicit apoptosis through complement-dependent cytotoxicity and antibodydependent cell-mediated cytotoxicity. Moreover, (4) macrophages $(\mathrm{M} \varphi)$ can bind to the antibody-antigen complex, which leads to the induction of immunosuppressive macrophages (Mpind) able to produce anti-inflammatory proteins, inhibit T-cell proliferation and promote wound healing

antibodies $[4,5,17]$. They further demonstrate that antiTNF antibodies are able to maintain remission up to 1 year in approximately $45-83 \%$ of patients. The variation in these remission rates largely depends on patient or treatment factors, as will be discussed further below. Anti-TNF antibodies are also effective in closing perianal fistulas in children with CD: after 2-4 months of treatment, approximately 64\% showed complete fistula closure (range $54-100 \%$ [18-20]), and after 1 year of treatment, 40-68\% showed complete closure [5, 20].

Unfortunately, there still is a lack of a direct, head-tohead comparison of the efficacy of anti-TNF monotherapy with that of the alternative therapies in use-EEN or corticosteroids for remission induction and thiopurines or MTX for remission maintenance [16]. The pivotal trials of both IFX and ADA in paediatric CD did not have a control group, and since their approval, no prospective trial has 
been published that compares the effectiveness of anti-TNF antibodies with alternative treatments. Currently, a trial is ongoing that compares the efficacy of remission induction with IFX, prednisolone or EEN in newly diagnosed paediatric CD patients, but results are not yet available [21]. Thus, there is currently no reliable way to compare the efficacy of anti-TNF antibodies to alternative treatment options.

\section{Optimising Treatment}

\subsection{Patient Characteristics Impacting Effectiveness}

Patient characteristics can have a high impact on drug effectiveness. In the pivotal ADA trial, IFX-experienced patients were only half as likely to achieve disease remission during follow-up than IFX-naïve patients [5]. Secondly, the authors reported that younger age and shorter disease duration were associated with higher remission rates, a finding confirmed by several observational trials [18, 22-24]. The third factor influencing remission rates in this trial was baseline C-reactive protein (CRP). Patients with lower CRP were more likely to achieve remission during follow-up. However, this finding conflicts with literature in adult CD patients, where several trials found high baseline CRP to be associated with higher remission rates [25-27].

\subsection{Combination Therapy and Therapeutic Drug Monitoring}

Besides patient characteristics, some treatment options are known to impact treatment effectiveness and allow further treatment optimisation. Currently, there are two methods being used to improve the effectiveness of anti-TNF antibodies: combination therapy with an immunomodulator and monitoring of therapeutic drug levels (TDM). Evidence on the relative higher effectiveness of combination therapy comes from adult CD literature. The Study of Biologic and Immunomodulator Naive Patients in Crohn's Disease (SONIC) trial [28] in adult CD patients who were naïve to azathioprine (AZA) and anti-TNF antibodies demonstrated that the addition of AZA to IFX treatment increases the rate of corticosteroid-free remission and endoscopic remission at 1 year. However, this result was achieved in AZA-naïve patients, and it is not known if combination therapy is also superior in AZA refractory patients, which is important since many paediatric CD patients indicated for anti-TNF therapy are AZA refractory. Additionally, adult CD literature demonstrates that concomitant immunomodulatory usage increases anti-TNF drug levels and reduces their immunogenicity rates, which may explain the increase in treatment effectiveness [29]. Thus, although evidence of increased effectiveness is lacking in paediatric $\mathrm{CD}$, based on adult $\mathrm{CD}$ literature, it is likely that combination therapy is more effective, at the cost of increased risk of adverse effects. The current CD treatment guideline thus suggests to "allow concomitant AZA treatment in the first 6 months of IFX therapy and then consider stopping AZA, but individualization of the strategy is required based on prediction variables" [16].

Another method used to increase effectiveness is TDM. Drug level measurements are typically timed preceding an infusion, resulting in trough levels. IFX trough levels are considered therapeutic when roughly between 3 and $7 \mu \mathrm{g} /$ ml, based on adult CD literature [30-32]. Whether TDM increases the effectiveness of IFX has not been tested in paediatric $\mathrm{CD}$, but a prospective, randomised controlled trial (RCT) assessed this in adult IBD patients with stable response to maintenance IFX [33]. This trial showed that dose screening and optimisation during stable response was able to increase the rate of remission in patients with sub-therapeutic levels. Subsequent TDM was demonstrated more cost-effective than clinically based dosing over a 1-year follow-up period. It did not increase 1-year remission rates-the primary efficacy endpoint-but it did reduce the number of flares [TDMvs clinically based dosing: 1 year remission $69 \%(88 / 128)$ vs $66 \%(81 / 123), P=0.686$; patients with flares $7 \%(9 /$ $128)$ vs $17 \%(21 / 123), P=0.018]$. Additionally, a second RCT compared dose intensification of IFX based on TDM versus that based on clinical symptoms; results are only available as an abstract [34]. Adult CD patients who started with IFX induction $(5 \mathrm{mg} / \mathrm{kg})$ were randomised at week 14 into 3 groups: two groups received TDM-based dose intensification and one received dose intensification based on clinical symptoms alone. After 1 year, TDMbased dose intensifications had not led to higher effectiveness in the primary outcome, i.e. steroid-free remission plus endoscopic absence of ulcers [TDM 21/45 (47\%) and 14/37 (38\%) vs clinically based 16/40 (40\%), $P=$ not significant]. Thus, in adult CD patients, TDM does not always increase the effectiveness of IFX. So far, it has only been demonstrated beneficial in patients in stable remission under IFX treatment, by reducing the risk of sub-therapeutic levels, and by increasing cost-effectiveness. Since the risk of sub-therapeutic IFX levels is higher in paediatrics, TDM may be more beneficial for children than for adults [35]. Moreover, since both studies included IBD patients on maintenance, it could be more beneficial to start TDM at IFX induction. Thus, the value of TDM needs to be tested in paediatric patients separately. Also, when faced with loss of response, TDM can guide therapeutic decision making $[16,36]$. 


\subsection{Predicting Treatment Response}

Predicting patients' chances to respond to available treatment options can improve overall treatment success by enabling physicians to directly choose the treatment option that offers the highest chance for response-also known as precision treatment. There are three different ways in which treatment outcome prediction can improve overall treatment success (Fig. 2). The first is predicting-before treatment initiation-which patients respond to anti-TNF treatment and do not respond to alternative treatment options. Since $80-90 \%$ of paediatric CD patients respond to anti-TNF antibodies, research should focus on predicting who does not respond to alternative treatment options, e.g. steroids, EEN and immunomodulators, to limit the delay of effective treatment initiation. Unfortunately, there are only very limited data published on this matter. Two trials assessed predictive markers for steroid responsiveness in adult IBD patients. Montero-Melendez et al. performed RNA expression profiling on mucosal biopsies from 28 IBD patients, including $13 \mathrm{CD}$ patients, before they started

Anti-TNF antibody treatment

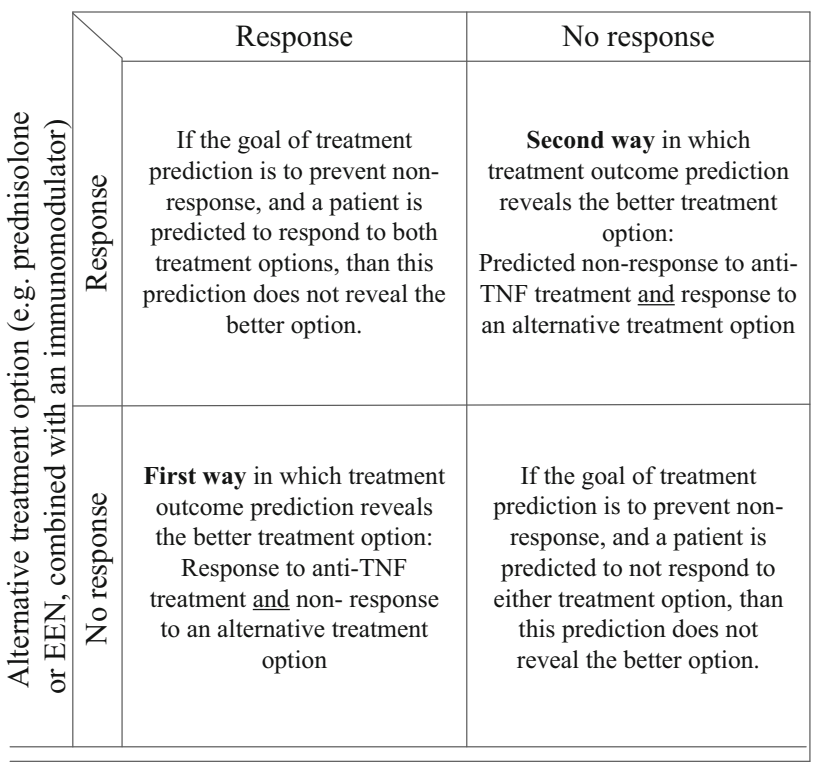

Third way: Once anti-TNF treatment is initiated, patients benefit from a timely recognition of a disease relapse. Predicting which patients have high risk to lose response helps to timely recognise and act on a relapse.

Fig. 2 Ways in which patients may benefit from treatment outcome prediction. Displayed are the three ways in which Crohn's disease (CD) patients may benefit from treatment outcome prediction related to anti-tumour necrosis factor (TNF) treatment. The goal or object of the first two ways of treatment prediction is the same-to prevent treatment non-response. This can only be achieved by an accurate prediction of the chance to respond to anti-TNF treatment and a prediction of the chance to respond to an alternative treatment option. The third way in which treatment outcome prediction can be beneficial is by predicting which patients are at high risk of losing response. EEN exclusive enteral nutrition with steroid treatment [37]. With the aim of finding the fewest number of genes with the highest accuracy, the authors identified a set of 35 genes that could predict steroid response (sensitive vs resistant within 30 days) with $82 \%$ accuracy. This finding still needs replication in paediatric CD patients. Additionally, in adult ulcerative colitis (UC) patients, RNA expression positivity of glucocorticoid receptor $\beta$ (GR- $\beta$ ) was found to correlate with response to steroids in two separate cohorts [first [38] and second [39] cohort: $83 \%(10 / 12)$ and $88 \%(7 / 8)$ positivity in steroidresistant vs $9 \%$ (1/11) and 17\% (1/6) in steroid-responsive patients]. No data are published on the relation between GR- $\beta$ and steroid responsiveness in CD patients. Concerning predicting thiopurines' effectiveness, a method to predict their tolerability is clinically available: patients with low or extremely low thiopurine S-methyltransferase (TPMT) activity are at increased risk of drug-induced bone-marrow toxicity [40]. By measuring TPMT enzyme activity and not commencing thiopurines in patients with extremely low TPMT activity, the risk of treatment failure is reduced. Some data on predicting MTX responsiveness are available in the field of adult rheumatology [41], but this has not been addressed in IBD. Neither are data available for predicting response to EEN. Thus, only very limited data are available on predicting responsiveness to the alternative non-biologic treatment options.

The second way to increase the chance of treatment success is by predicting who does not respond to anti-TNF antibodies and may better receive an alternative treatment option. Research on this topic is complicated by the low chance of primary non-response in paediatric $\mathrm{CD}$, and demands relatively large patient samples in order to be studied. As we discussed previously, some patient characteristics are known to impact anti-TNF treatment success, i.e. no previous anti-TNF exposure, younger age and shorter disease duration are associated with higher antiTNF response rates. However, these features are currently not used to determine who should or should not receive anti-TNF treatment, since they cannot accurately predict anti-TNF primary non-response-one exception being IFX non-responders, who are switched to a drug that does not target TNF. In adult $\mathrm{CD}$, not in paediatric $\mathrm{CD}$, several trials have sought baseline biomarkers that can predict anti-TNF response. Response to anti-TNF antibodies has been associated with baseline RNA expression of several genes in mucosal biopsies [42] and peripheral blood [43], and with the patients' genetic make-up [44-49]. Arijs et al. demonstrated that RNA expression profiles of mucosal biopsies from adult colonic $\mathrm{CD}$ patients were able to accurately distinguish all IFX responders from IFX nonresponders-response was determined based on change in endoscopic disease severity at week 4-6 [42]. The authors reported that the top 5 differentially expressed genes alone 
reached perfect accuracy, i.e. 100\% [top five genes: TNF-ainduced protein 6 (TNFAIP6), S100 calcium-binding protein A8 (S100A8), interleukin-11, G0/G1switch 2 (G0S2), and S100 calcium-binding protein A9 (S100A9)]. No such predictive gene set was identified in ileal CD patients. More recently, West et al. reported high oncostatin M expression in mucosal tissue to be associated with antiTNF response, which may be a promising marker in the future [50]. These findings now require replication in a separate cohort of paediatric CD patients before they can be used in clinical practice to guide treatment choices. Atreya et al. used a novel approach to predict anti-TNF response in adult $\mathrm{CD}$ patients [51]. They performed endoscopy with an endomicroscope, which enables microscopic inspection of the patient's intestinal mucosal surface. Mucosal tmTNF${ }^{+}$cells in the intestine were then visualised in vivo by application of fluorescent antibodies to TNF. Based on the number of tmTNF ${ }^{+}$cells, the authors were able to predict week-12 anti-TNF response with a sensitivity of $85 \%$ and a specificity of $92 \%$. However, since the response rate they found in adult $\mathrm{CD}$ patients was much lower than that known in children, results cannot be simply extrapolated to children, but require a specific analysis of this method in children with CD. Furthermore, the use of these techniques currently remains highly restricted, as most centres neither have access to nor experience with endomicroscopy, which limits its application.

Thirdly, it would be beneficial to predict patients at risk of losing response to anti-TNF antibodies during treatment, since these patients may need intensified treatment and more frequent follow-up. There are multiple trials that addressed this topic. Typically they have a follow-up period of 1 year and measure a certain marker after the induction period (roughly at 2-4 months from anti-TNF antibody initiation) and relate these results to their 1-year effectiveness outcomes. When measured after the induction period, lower clinical disease activity [5], lower endoscopic disease activity [52], lower calprotectin concentrations [53], lower disease activity measured by sonography [54] or by magnetic resonance enterography [55, 56], and higher IFX trough levels $[32,57]$ are associated with longer disease remission. In short, all available evidence indicates that more effective induction treatment results in more durable disease remission. Assessment of most of these factors is already part of routine clinical assessment and assists in timely discovery of treatment inefficacy.

\section{Risk of Malignancy}

Anti-TNF antibodies have been in use for about 2 decades and most adverse effects are well established. Serious side effects include acute and delayed infusion reactions, serious infections and opportunistic infections $[4,5,16,58,59]$. More uncertainty remains for rare but serious adverse events. These include rare cases of malignancies and mortality. Mortality in IBD patients is primarily linked to serious infections, followed by malignancy or uncontrolled disease [60]. The risk of malignancies was thought to be increased by anti-TNF treatment, as cases of lymphoma and hepato-splenic T-cell lymphomas (HSTCLs) were being reported in CD patients treated with both anti-TNF antibodies and immunomodulators $[61,62]$. This was one of the reasons why, next to the increased serious infection risk, anti-TNF antibodies were only approved for therapy refractory $\mathrm{CD}$ patients, because of the higher benefit-risk ratio in this population [63].

Recently, new evidence suggests that the risk of lymphoma seems more linked to thiopurine use ( \pm in combination with anti-TNF) than anti-TNF treatment in itself. A large industry-sponsored, long-term observational registry of paediatric patients with IBD (DEVELOP; NCT00606346) was initiated in 2007 to evaluate the longterm safety profile of IFX and other therapies prescribed to paediatric IBD patients. In their first publication, using data from 5766 patients with a median follow-up of 4.7 years and a total of 18 malignancy events, the authors report that they did not find an increased risk of malignancy and hemophagocytic lymphohistiocytosis (HLH) in IFX-treated patients compared to a non-CD control population. Instead these risks were increased in thiopurinetreated patients-with or without biologic exposure [64]. Notably, all (five) HLH cases were patients exposed to thiopurine and either a primary Epstein Barr virus infection (4/5) or a cytomegalovirus infection (1/5); none had been exposed to anti-TNF antibodies. Out of 15 malignancy cases, four were thiopurine related and without anti-TNF antibody exposure; in the remaining 11 malignancy cases, patients were exposed to both thiopurines and anti-TNF antibodies. Note that these conclusions were based on exposure defined as 'ever exposed', and in their discussion the authors acknowledged that, based on their data, cessation of thiopurine treatment for more than 1 year reduced the malignancy risk, approaching the baseline risk. Nevertheless, IFX alone did not significantly increase the malignancy risk; this was only the case when patients were also-previously or currently-exposed to thiopurine. This was also the conclusion of a case-control study on the risk of lymphomas, which reported an increased risk of T-cell lymphoma for combination therapy (anti-TNF treatment plus thiopurines), but not for anti-TNF treatment alone [65]. These findings imply a somewhat more favourable benefit-risk ratio of anti-TNF treatment than previously assumed, especially when given as monotherapy—without thiopurines. 


\section{Who to Treat and When to Start}

Both IFX and ADA were only approved for a restricted population of paediatric $\mathrm{CD}$ patients, namely the therapy refractory patients with moderately-to-severely active disease. Yet, their benefit seems higher when given earlier in the course of disease. It may therefore be more beneficial to start anti-TNF antibodies right after diagnosis rather than delay the initiation. This is especially true for patients who are not effectively treated with-i.e. do not respond to or quickly relapse under-the conventional non-biologic treatment options (prednisolone or EEN, combined with AZA or MTX). However, it remains difficult to predict responsiveness to these therapeutic options, so further research is needed to assess the benefits (and risks) of starting anti-TNF antibodies as a first-line treatment option.

An argument to limit the use of anti-TNF antibodies is that they are much more expensive than alternative nonbiologic treatment options. However, the prices of antiTNF antibodies are bound to fall after the expiration of their patents and the approval of an increasing number of biosimilars. Secondly, if anti-TNF antibodies are indeed more effective than their non-biologic treatment alternatives, this increased efficacy will cause healthcare savings over time. Reduced costs will improve the cost-effectiveness of anti-TNF antibodies, which, together with a slightly more favourable safety profile, are arguments for a wider use of the drug in the future.

Patients at greater risk of disease complication, such as strictures and fistulae, would benefit most from an early initiation with anti-TNF antibodies. For this purpose, the current guidelines lists seven factors as potentially predictive of poor outcome-mostly based on clinical experience [16]. Recently, new results of the Risk Stratification and Identification of Immunogenetic and Microbial Markers of Rapid Disease Progression in Children with Crohn's Disease (RISK) study were published [66]. This prospective inception cohort study followed 913 paediatric CD patients from disease onset up to 3 years after. Baseline predictive factors for stricturing or penetrating disease at 3 years were older age, African-American race, isolated ileal disease, and ASCA and CBir1 serum positivity. However, their combined sensitivity and specificity were low [66\% (95\% confidence interval 51-82) and 63\% (95\% confidence interval) [55-71]. The authors state that the accuracy was low because of the low prevalence of complications in their cohort. Due to the low accuracy, the significance of these predictive factors in clinical decision making is limited. Thus it remains difficult to accurately determine patients at high risk of complications.

\section{Biosimilars}

Biosimilars of IFX have become available on the European market since the expiration of the patent of the IFX originator Remicade ${ }^{\circledR}$. The similarity between the IFX biosimilar CT-P13 (Inflectra ${ }^{\circledR}$, Remsima ${ }^{\circledR}$ ) and Remicade ${ }^{\circledR}$ was extensively tested in pre-clinical tests by comparing the treatments' physicochemical characteristics and by comparing their biological activities in several models related to their mechanisms of action. Afterwards, their similarity was confirmed clinically in two of the indications of IFX: ankylosing spondylitis and rheumatoid arthritis $[67,68]$. Based on these results, CT-P13 received market approval for all IFX's indications, including paediatric CD.

Only recently, the results of a randomised, double-blind, non-inferiority trial were published comparing the efficacy and safety of continuing on Remicade ${ }^{\circledR}$ with switching to CT-P13 in patients with various diseases including CD on stable treatment with Remicade ${ }^{\circledR}$ [69]. A total of 482 patients (155 CD patients; 32\%) with stable conditions under IFX treatment were randomised to continue on Remicade ${ }^{\circledR}$ or switch to CT-P13. After 1 year of follow-up, they reported similar rates of disease worsening (Remicade $^{\circledR}$ vs CT-P13: 26 vs $30 \%$ ) and similar rates of adverse events (adverse events 70 vs 68\%; serious adverse events 10 vs $9 \%$ ). Notably, the study was not powered to show non-inferiority in CD specifically, but in the overall population. Additionally, multiple observational trials assessed the effects of switching from Remicade ${ }^{\circledR}$ to CT-P13, and these were recently combined in a systematic review [70]. The authors combined the data from 11 observational trials and 1007 IBD patients, and compared these results-i.e. efficacy, safety and immunogenicity rates of CT-P13with the results of Remicade ${ }^{\circledR}$ as reported in previously published trials. Again, they reported no significant differences. Currently, only one observational trial assessed the effect of switching to CT-P13 in paediatric CD [71]. A total of 32 paediatric $\mathrm{CD}$ patients-and $7 \mathrm{UC}$-were switched from Remicade ${ }^{\circledR}$ to CT-P13. The authors report that switching seemed to be safe and did not impact efficacy. Thus, the early results confirm the expected similarity of Remicade ${ }^{\circledR}$ and CT-P13 in CD. Yet studies on both long-term outcome and switching from the originator to the biosimilar in paediatric $\mathrm{CD}$ are still required.

\section{Conclusions}

Anti-TNF antibody treatment is very beneficial for paediatric $\mathrm{CD}$ patients. Ongoing research is revealing methods to improve its effectiveness, such as early start after diagnosis, 
TDM and combination treatment with an immunomodulator. Precision treatment could also optimise anti-TNF treatment effectiveness by improving response rates and preventing ineffective treatment. While multiple predictive markers are identified in adult CD patients, data on their accuracy in paediatric $\mathrm{CD}$ patients is lagging behind. As stated, the assumed increased risk of malignancies under anti-TNF and thiopurine combination treatment now seems more linked to thiopurines, revealing a slightly more favourable safety profile for anti-TNF treatment than assumed, specifically when given as monotherapy. In addition, the early results of IFX biosimilar CT-P13 in CD patients confirm the expected similarity to its originator regarding efficacy and safety. In summary, the effectiveness of anti-TNF antibody treatment is slowly improving, its risks seem somewhat lower than assumed, and its costs are reduced by the introduction of probably equally effective biosimilars. Together, these trends allow for a more prominent role for anti-TNF antibodies in future treatment of paediatric CD.

\section{Compliance with Ethical Standards}

Funding No funding was received for the preparation of this manuscript. Open access funding was provided through an agreement between SpringerNature and the Association of Dutch Universities.

Conflict of interest MC and JS have no conflicts of interest to declare. LdR reports research grants from ZonMw (Dutch Health Organisation), Crocokids, and Pfizer (before Hospira); consulting fees from Abbvie, Mundipharma and Shire; and lecture fees from Abbvie.

Open Access This article is distributed under the terms of the Creative Commons Attribution-NonCommercial 4.0 International License (http://creativecommons.org/licenses/by-nc/4.0/), which permits any noncommercial use, distribution, and reproduction in any medium, provided you give appropriate credit to the original author(s) and the source, provide a link to the Creative Commons license, and indicate if changes were made.

\section{References}

1. Benchimol EI, Fortinsky KJ, Gozdyra P, Van den Heuvel M, Van Limbergen J, Griffiths AM. Epidemiology of pediatric inflammatory bowel disease: a systematic review of international trends. Inflamm Bowel Dis. 2011;17(1):423-39.

2. Van Limbergen J, Russell RK, Drummond HE, Aldhous MC, Round NK, Nimmo ER, et al. Definition of phenotypic characteristics of childhood-onset inflammatory bowel disease. Gastroenterology. 2008;135(4):1114-22.

3. Pigneur B, Seksik P, Viola S, Viala J, Beaugerie L, Girardet JP, et al. Natural history of Crohn's disease: comparison between childhood- and adult-onset disease. Inflamm Bowel Dis. 2010;16(6):953-61.

4. Hyams J, Crandall W, Kugathasan S, Griffiths A, Olson A, Johanns J, et al. Induction and maintenance infliximab therapy for the treatment of moderate-to-severe Crohn's disease in children. Gastroenterology. 2007;132(3):863-73.

5. Hyams JS, Griffiths A, Markowitz J, Baldassano RN, Faubion Wa, Colletti RB, et al. Safety and efficacy of adalimumab for moderate to severe Crohn's disease in children. Gastroenterology. 2012;143(2):365-74.e2.

6. Fan R, Zhong J, Wang ZT, Li SY, Zhou J, Tang YH. Evaluation of "top-down" treatment of early Crohn's disease by double balloon enteroscopy. World J Gastroenterol. 2014;20(39):14479-87.

7. Mannon PJ, Fuss IJ, Mayer L, Elson CO, Sandborn WJ, Present D, et al. Anti-interleukin-12 antibody for active Crohn's disease. N Engl J Med. 2004;351(20):2069-79.

8. Tracey D, Klareskog L, Sasso EH, Salfeld JG, Tak PP. Tumor necrosis factor antagonist mechanisms of action: a comprehensive review. Pharmacol Ther. 2008;117(2):244-79.

9. ten Hove T, van Montfrans C, Peppelenbosch MP, van Deventer SJ. Infliximab treatment induces apoptosis of lamina propria $\mathrm{T}$ lymphocytes in Crohn's disease. Gut. 2002;50(2):206-11.

10. Mitoma H, Horiuchi T, Hatta N, Tsukamoto H, Harashima S, Kikuchi $\mathrm{Y}$, et al. Infliximab induces potent anti-inflammatory responses by outside-to-inside signals through transmembrane TNF-alpha. Gastroenterology. 2005;128(2):376-92.

11. Sandborn WJ, Hanauer SB, Katz S, Safdi M, Wolf DG, Baerg $\mathrm{RD}$, et al. Etanercept for active Crohn's disease: a randomized, double-blind, placebo-controlled trial. Gastroenterology. 2001;121(5):1088-94.

12. Schreiber S, Rutgeerts $P$, Fedorak RN, Khaliq-Kareemi M, Kamm MA, Boivin M, et al. A randomized, placebo-controlled trial of certolizumab pegol (CDP870) for treatment of Crohn's disease. Gastroenterology. 2005;129(3):807-18.

13. Nesbitt A, Fossati G, Bergin M, Stephens P, Stephens S, Foulkes $\mathrm{R}$, et al. Mechanism of action of certolizumab pegol (CDP870): in vitro comparison with other anti-tumor necrosis factor alpha agents. Inflamm Bowel Dis. 2007;13(11):1323-32.

14. Vos AC, Wildenberg ME, Arijs I, Duijvestein M, Verhaar AP, de Hertogh G, et al. Regulatory macrophages induced by infliximab are involved in healing in vivo and in vitro. Inflamm Bowel Dis. 2012;18(3):401-8.

15. Vos AC, Wildenberg ME, Duijvestein M, Verhaar AP, van den Brink GR, Hommes DW. Anti-tumor necrosis factor-alpha antibodies induce regulatory macrophages in an Fc region-dependent manner. Gastroenterology. 2011;140(1):221-30.

16. Ruemmele FM, Veres G, Kolho KL, Griffiths A, Levine A, Escher JC, et al. Consensus guidelines of ECCO/ESPGHAN on the medical management of pediatric Crohn's disease. J Crohns Colitis. 2014;8(10):1179-207.

17. Ruemmele FM, Lachaux A, Cézard J-P, Morali A, Maurage C, Giniès J-L, et al. Efficacy of infliximab in pediatric Crohn's disease: a randomized multicenter open-label trial comparing scheduled to on demand maintenance therapy. Inflamm Bowel Dis. 2009;15:388-94.

18. Lionetti P, Bronzini F, Salvestrini C, Bascietto C, Canani RB, De Angelis GL, et al. Response to infliximab is related to disease duration in paediatric Crohn's disease. Aliment Pharmacol Ther. 2003; 18(4):425-31.

19. Cezard JP, Nouaili N, Talbotec C, Hugot JP, Gobert JG, Schmitz J, et al. A prospective study of the efficacy and tolerance of a chimeric antibody to tumor necrosis factors (Remicade) in severe pediatric crohn disease. J Pediatr Gastroenterol Nutr. 2003;36(5):632-6.

20. Crandall W, Hyams J, Kugathasan S, Griffiths A, Zrubek J, Olson A, et al. Infliximab therapy in children with concurrent perianal Crohn disease: observations from REACH. J Pediatr Gastroenterol Nutr. 2009;49:183-90.

21. Cozijnsen MA, van Pieterson M, Samsom JN, Escher JC, de Ridder L. Top-down Infliximab Study in Kids with Crohn's disease (TISKids): an international multicentre randomised controlled trial. BMJ Open Gastroenterol. 2016;3(1):e000123.

22. Cozijnsen MA, de Ridder L. Infliximab more effective in therapynaive than in therapy-refractory patients. J Pediatr Gastroenterol Nutr. 2015;61(3):e15. 
23. Kugathasan S, Werlin SL, Martinez A, Rivera MT, Heikenen JB, Binion DG. Prolonged duration of response to infliximab in early but not late pediatric Crohn's disease. Am J Gastroenterol. 2000;95(11):3189-94.

24. Cameron FL, Altowati MA, Rogers P, McGrogan P, Anderson N, Bisset WM, et al. Disease status and pubertal stage predict improved growth in antitumor necrosis factor therapy for pediatric inflammatory bowel disease. J Pediatr Gastroenterol Nutr. 2017;64(1):47-55.

25. Sandborn WJ, Colombel JF, D'Haens G, Plevy SE, Panes J, Robinson AM, et al. Association of baseline C-reactive protein and prior anti-tumor necrosis factor therapy with need for weekly dosing during maintenance therapy with adalimumab in patients with moderate to severe Crohn's disease. Curr Med Res Opin. 2013;29(5):483-93.

26. Reinisch W, Wang Y, Oddens BJ, Link R. C-reactive protein, an indicator for maintained response or remission to infliximab in patients with Crohn's disease: a post-hoc analysis from ACCENT I. Aliment Pharmacol Ther. 2012;35:568-76.

27. Vermeire S, Van Assche G, Rutgeerts P. C-reactive protein as a marker for inflammatory bowel disease. Inflamm Bowel Dis. 2004;10(5):661-5.

28. Colombel JF, Sandborn WJ, Reinisch W, Mantzaris GJ, Kornbluth A, Rachmilewitz D, et al. Infliximab, azathioprine, or combination therapy for Crohn's disease. $N$ Engl J Med. 2010;362:1383-95.

29. Cozijnsen MA, Escher JC, Griffiths A, Turner D, de Ridder L. Benefits and risks of combining anti-tumor necrosis factor with immunomodulator therapy in pediatric inflammatory bowel disease. Inflamm Bowel Dis. 2015;21(4):951-61.

30. Levesque BG, Greenberg GR, Zou G, Sandborn WJ, Singh S, Hauenstein $S$, et al. A prospective cohort study to determine the relationship between serum infliximab concentration and efficacy in patients with luminal Crohn's disease. Aliment Pharmacol Ther. 2014;39(10):1126-35.

31. Cornillie F, Hanauer SB, Diamond RH, Wang J, Tang KL, Xu Z, et al. Postinduction serum infliximab trough level and decrease of C-reactive protein level are associated with durable sustained response to infliximab: a retrospective analysis of the ACCENT I trial. Gut. 2014;63(11):1721-7.

32. Bortlik M, Duricova D, Malickova K, Machkova N, Bouzkova E, Hrdlicka L, et al. Infliximab trough levels may predict sustained response to infliximab in patients with Crohn's disease. J Crohns Colitis. 2013;7(9):736-43.

33. Vande Casteele N, Ferrante M, Van Assche G, Ballet V, Compernolle G, Van Steen K, et al. Trough concentrations of infliximab guide dosing for patients with inflammatory bowel disease. Gastroenterology. 2015;148(7):1320-9 e3.

34. D'Haens G, Vermeire S, Lambrecht G, Baert F, Bossuyt P, Nachury M, et al. 692 Drug-Level Based Dosing Versus Symptom-Based Dose Adaptation in Patients With Crohn's Disease: A Prospective, Randomized Multicenter Study (TAILORIX). Gastroenterology. 2016;150(4 SUPPL 1):S143.

35. Hofmekler T, Bertha M, McCracken C, Martineau B, McKinnon E, Schoen BT, et al. Infliximab optimization based on therapeutic drug monitoring in pediatric inflammatory bowel disease. J Pediatr Gastroenterol Nutr. 2017;64(4):580-5.

36. Minar P, Saeed SA, Afreen M, Kim MO, Denson LA. Practical use of infliximab concentration monitoring in pediatric Crohn disease. J Pediatr Gastroenterol Nutr. 2016;62(5):715-22.

37. Montero-Melendez T, Llor X, Garcia-Planella E, Perretti M, Suarez A. Identification of novel predictor classifiers for inflammatory bowel disease by gene expression profiling. PLoS One. 2013;8(10):e76235.

38. Honda M, Orii F, Ayabe T, Imai S, Ashida T, Obara T, et al. Expression of glucocorticoid receptor beta in lymphocytes of patients with glucocorticoid-resistant ulcerative colitis. Gastroenterology. 2000;118(5):859-66.

39. Fujishima S, Takeda H, Kawata S, Yamakawa M. The relationship between the expression of the glucocorticoid receptor in biopsied colonic mucosa and the glucocorticoid responsiveness of ulcerative colitis patients. Clin Immunol. 2009;133(2):208-17.

40. Gisbert JP, Nino P, Rodrigo L, Cara C, Guijarro LG. Thiopurine methyltransferase (TPMT) activity and adverse effects of azathioprine in inflammatory bowel disease: long-term follow-up study of 394 patients. Am J Gastroenterol. 2006;101(12): 2769-76.

41. Urano W, Taniguchi A, Yamanaka H, Tanaka E, Nakajima H, Matsuda Y, et al. Polymorphisms in the methylenetetrahydrofolate reductase gene were associated with both the efficacy and the toxicity of methotrexate used for the treatment of rheumatoid arthritis, as evidenced by single locus and haplotype analyses. Pharmacogenetics. 2002;12(3):183-90.

42. Arijs I, Quintens R, Van Lommel L, Van Steen K, De Hertogh G, Lemaire K, et al. Predictive value of epithelial gene expression profiles for response to infliximab in Crohn's disease. Inflamm Bowel Dis. 2010;16(12):2090-8.

43. Mesko B, Poliska S, Vancsa A, Szekanecz Z, Palatka K, Hollo Z, et al. Peripheral blood derived gene panels predict response to infliximab in rheumatoid arthritis and Crohn's disease. Genome Med. 2013;5(6):59.

44. Pierik M, Vermeire S, Steen KV, Joossens S, Claessens G, Vlietinck R, et al. Tumour necrosis factor-alpha receptor 1 and 2 polymorphisms in inflammatory bowel disease and their association with response to infliximab. Aliment Pharmacol Ther. 2004;20(3):303-10.

45. Matsukura H, Ikeda S, Yoshimura N, Takazoe M, Muramatsu M. Genetic polymorphisms of tumour necrosis factor receptor superfamily $1 \mathrm{~A}$ and $1 \mathrm{~B}$ affect responses to infliximab in Japanese patients with Crohn's disease. Aliment Pharmacol Ther. 2008;27(9):765-70.

46. Billiet T, Papamichael K, de Bruyn M, Verstockt B, Cleynen I, Princen F, et al. A matrix-based model predicts primary response to infliximab in Crohn's disease. J Crohns Colitis. 2015;9(12): 1120-6.

47. Vermeire S, Van Assche G, Rutgeerts P. Role of genetics in prediction of disease course and response to therapy. World $\mathrm{J}$ Gastroenterol. 2010;16(21):2609-15.

48. Repnik K, Koder S, Skok P, Ferkolj I, Potocnik U. Transferrin level before treatment and genetic polymorphism in HFE gene as predictive markers for response to adalimumab in Crohn's disease patients. Biochem Genet. 2016;54(4):476-86.

49. Barber GE, Yajnik V, Khalili H, Giallourakis C, Garber J, Xavier $\mathrm{R}$, et al. Genetic markers predict primary non-response and durable response to anti-TNF biologic therapies in Crohn's disease. Am J Gastroenterol. 2016;111(12):1816-22.

50. West NR, Hegazy AN, Owens BMJ, Bullers SJ, Linggi B, Buonocore S, et al. Oncostatin $\mathrm{M}$ drives intestinal inflammation and predicts response to tumor necrosis factor-neutralizing therapy in patients with inflammatory bowel disease. Nat Med. 2017;23(5):579-89.

51. Atreya R, Neumann H, Neufert C, Waldner MJ, Billmeier U, Zopf $\mathrm{Y}$, et al. In vivo imaging using fluorescent antibodies to tumor necrosis factor predicts therapeutic response in Crohn's disease. Nat Med. 2014.

52. af Bjorkesten CG, Nieminen U, Sipponen T, Turunen U, Arkkila $\mathrm{P}$, Farkkila M, et al. Mucosal healing at 3 months predicts longterm endoscopic remission in anti-TNF-treated luminal Crohn's disease. Scand J Gastroenterol. 2013;48(5):543-51.

53. Boschetti G, Garnero P, Moussata D, Cuerq C, Preaudat C, Duclaux-Loras R, et al. Accuracies of serum and fecal S100 proteins (calprotectin and calgranulin $\mathrm{C}$ ) to predict the response 
to TNF antagonists in patients with Crohn's disease. Inflamm Bowel Dis. 2015;21(2):331-6.

54. Ripolles T, Paredes JM, Martinez-Perez MJ, Rimola J, JaureguiAmezaga A, Bouzas R, et al. Ultrasonographic changes at 12 weeks of anti-TNF drugs predict 1-year sonographic response and clinical outcome in Crohn's disease: a multicenter study. Inflamm Bowel Dis. 2016;22(10):2465-73.

55. Buisson A, Hordonneau C, Goutte M, Scanzi J, Goutorbe F, Klotz $\mathrm{T}$, et al. Diffusion-weighted magnetic resonance enterocolonography in predicting remission after anti-TNF induction therapy in Crohn's disease. Dig Liver Dis. 2016;48(3):260-6.

56. Naganuma M, Okuda S, Hisamatsu T, Matsuoka K, Mori K, Hosoe N, et al. Findings of ulceration and severe stricture on MRE can predict prognosis of Crohn's disease in patients treated with anti-TNF treatment. Abdom Radiol (NY). 2017;42(1): 141-51.

57. Stein R, Lee D, Leonard MB, Thayu M, Denson LA, Chuang E, et al. Serum infliximab, antidrug antibodies, and tumor necrosis factor predict sustained response in pediatric Crohn's disease. Inflamm Bowel Dis. 2016;22(6):1370-7.

58. Rahier JF, Ben-Horin S, Chowers Y, Conlon C, De Munter P, D'Haens G, et al. European evidence-based Consensus on the prevention, diagnosis and management of opportunistic infections in inflammatory bowel disease. J Crohns Colitis. 2009;3(2): 47-91.

59. Veereman-Wauters G, de Ridder L, Veres G, Kolacek S, Fell J, Malmborg P, et al. Risk of infection and prevention in pediatric patients with IBD: ESPGHAN IBD Porto Group commentary. J Pediatr Gastroenterol Nutr. 2012;54(6):830-7.

60. de Ridder L, Turner D, Wilson DC, Koletzko S, Martin-de-Carpi J, Fagerberg UL, et al. Malignancy and mortality in pediatric patients with inflammatory bowel disease: a multinational study from the porto pediatric IBD group. Inflamm Bowel Dis. 2014;20(2):291-300.

61. Siegel CA, Marden SM, Persing SM, Larson RJ, Sands BE. Risk of lymphoma associated with combination anti-tumor necrosis factor and immunomodulator therapy for the treatment of Crohn's disease: a meta-analysis. Clin Gastroenterol Hepatol. 2009;7(8): 874-81.

62. Kotlyar DS, Osterman MT, Diamond RH, Porter D, Blonski WC, Wasik M, et al. A systematic review of factors that contribute to hepatosplenic T-cell lymphoma in patients with inflammatory bowel disease. Clin Gastroenterol Hepatol. 2011;9(1):36-41 e1.

63. CHMP. Remicade-H-C-240-II-0075 : EPAR - Scientific Discussion-Variation. 2007. http://www.ema.europa.eu/docs/en_GB/
document_library/EPAR_-_Scientific_Discussion_-_Variation/ human/000240/WC500051562.pdf2007.

64. Hyams JS, Dubinsky MC, Baldassano RN, Colletti RB, Cucchiara S, Escher $\mathrm{J}$, et al. Infliximab is not associated with increased risk of malignancy or hemophagocytic lymphohistiocytosis in pediatric patients with inflammatory bowel disease. Gastroenterology. 2017:152(8):1901-14.

65. Deepak P, Sifuentes H, Sherid M, Stobaugh D, Sadozai Y, Ehrenpreis ED. T-cell non-Hodgkin's lymphomas reported to the FDA AERS with tumor necrosis factor-alpha (TNF-alpha) inhibitors: results of the REFURBISH study. Am J Gastroenterol. 2013;108(1):99-105.

66. Kugathasan S, Denson LA, Walters TD, Kim MO, Marigorta UM, Schirmer M, et al. Prediction of complicated disease course for children newly diagnosed with Crohn's disease: a multicentre inception cohort study. Lancet. 2017;389(10080):1710-8.

67. Yoo DH, Hrycaj P, Miranda P, Ramiterre E, Piotrowski M, Shevchuk S, et al. A randomised, double-blind, parallel-group study to demonstrate equivalence in efficacy and safety of CTP13 compared with innovator infliximab when coadministered with methotrexate in patients with active rheumatoid arthritis: the PLANETRA study. Ann Rheum Dis. 2013;72(10):1613-20.

68. Park W, Hrycaj P, Jeka S, Kovalenko V, Lysenko G, Miranda P, et al. A randomised, double-blind, multicentre, parallel-group, prospective study comparing the pharmacokinetics, safety, and efficacy of CT-P13 and innovator infliximab in patients with ankylosing spondylitis: the PLANETAS study. Ann Rheum Dis. 2013;72(10):1605-12.

69. Jorgensen KK, Olsen IC, Goll GL, Lorentzen M, Bolstad N, Haavardsholm EA, et al. Switching from originator infliximab to biosimilar CT-P13 compared with maintained treatment with originator infliximab (NOR-SWITCH): a 52-week, randomised, doubleblind, non-inferiority trial. Lancet. 2017;389(10086):2304-16.

70. Radin M, Sciascia S, Roccatello D, Cuadrado MJ. Infliximab biosimilars in the treatment of inflammatory bowel diseases: a systematic review. BioDrugs. 2017;31(1):37-49.

71. Sieczkowska J, Jarzebicka D, Banaszkiewicz A, Plocek A, Gawronska A, Toporowska-Kowalska E, et al. Switching between infliximab originator and biosimilar in paediatric patients with inflammatory bowel disease. Preliminary observations. J Crohns Colitis. 2016;10(2):127-32. 